\title{
Olfactory Response of the Green Lacewing Chrysoperla Externa to Volatile Organic Compounds of Eucalyptus Urograndis
}

David Jackson Vieira Borges

Universidade Federal de Uberlandia

Rafael Aparecido Carvalho Souza

UFU: Universidade Federal de Uberlandia

Alberto de Oliveira

UFU: Universidade Federal de Uberlandia

Raquel Maria Ferreira de Sousa

UFU: Universidade Federal de Uberlandia

Jean Carlos Santos ( $\nabla$ jcsantosbio@gmail.com )

Universidade Federal de Sergipe https://orcid.org/0000-0001-6031-9193

\section{Research Article}

Keywords: Chemical composition, eucalyptol, a-Terpinyl acetate, olfactometer, plant-predator interactions, simulated herbivory

Posted Date: May 18th, 2021

DOl: https://doi.org/10.21203/rs.3.rs-523020/v1

License: (9) (1) This work is licensed under a Creative Commons Attribution 4.0 International License. Read Full License 
Olfactory response of the green lacewing Chrysoperla externa to volatile organic compounds of Eucalyptus urograndis

David Jackson Vieira Borges*1, Rafael Aparecido Carvalho Souza ${ }^{2}$, Alberto de Oliveira ${ }^{2}$, Raquel Maria Ferreira de Sousa ${ }^{2}$ Jean Carlos Santos ${ }^{3 *}$

${ }^{1}$ Pos-graduate Program in Ecology and Conservation of Natural Resources, Federal University of Uberlândia, Uberlândia, Minas Gerais, Brazil. E-mail: davidvieirabiologo@gmail.com

${ }^{2}$ Institute of Chemistry, Federal University of Uberlândia, Uberlândia, Minas Gerais, Brazil. E-mails: rafasouza27@ufu.br; alberto@ufu.br; rsousa@ufu.br

3* Department of Ecology, Federal University of Sergipe, São Cristóvão, Brazil. E-mail: jcsantosbio@ gmail.com

\section{Orcid numbers:}

David Jackson Vieira Borges - ORCID ID: 0000-0001-7451-2349

Rafael Aparecido Carvalho Souza - ORCID ID: 0000-0003-3472-4026

Alberto de Oliveira - ORCID ID: 0000-0002-7210-164X

Raquel Maria Ferreira de Sousa - ORCID ID: 0000-0003-1509-2721

Jean Carlos Santos - ORCID ID: 0000-0001-6031-9193 
Abstract The evaluation of the direct effects of the relationship between plants and predators without considering the participation of herbivores can provide vital information for the study of ecological interactions and integrated pest management. In this context, the present work studied the behavioral responses of Chrysoperla externa (Neuroptera: Chrysopidae) larvae to the volatile organic compounds of young and mature, undamaged and damaged leaves of Eucalyptus urograndis (Myrtaceae), and investigate the chemical composition of leaf essential oils and their effects on the green lacewing. The responses of the C. externa larvae to the odors emitted by leaves were evaluated by an experimental behavior test using a Y-tube olfactometer. The essential oil was extracted by hydrodistillation of the young and mature leaves with and without damage. The larvae respond attractively to the volatiles emitted without the participation of herbivores, and it selected preferentially odors emitted by young leaves with simulated herbivory. The chemical composition was analyzed using gas chromatography coupled with mass spectrometry. This research identified 32 compounds; some of them had not been identified in other studies. Young leaves had a higher content of essential oil compared to mature leaves. Among the compounds identified, eucalyptol, $\alpha$-Terpineol, Aromadendrene, and $\alpha$-Terpinyl acetate are the major compounds. An inversion in the content of eucalyptol (which decreases) and $\alpha$-terpinyl acetate (which increases) is observed when young and mature leaves are damage. Thus, this work contributed with basic data on the potential use of eucalyptus forests as maintainers of natural chrysopids populations.

Keywords Chemical composition, eucalyptol, $\alpha$-Terpinyl acetate, olfactometer, plant-predator interactions, simulated herbivory 


\section{Introduction}

Eucalyptus is a genus that originates from Australia, Tasmania, and other islands in Oceania, having about 730 species, of which only 20 are currently used for commercial purposes in the world (Júnior et al., 2014). Data from the Brazilian Tree Industry (IBÁ) show that the reforestation area corresponds to 7.84 million hectares with eucalyptus, pine, and other forest species (acacia, rubber, paricá, and teak) (IBÁ, 2019). These trees are used for cellulose and paper (35\%), steel and charcoal (13\%), wood panels and laminate flooring (6\%), and other purposes (IBÁ, 2019; Santarosa et al., 2014). For this reason, the forestry sector has great economic importance in Brazil. In 2018, this sector was responsible for R $\$ 86.6$ billion of gross domestic product (GDP), representing $1.3 \%$ of all wealth generated in the country and $6.9 \%$ of the industrial sector. This sector is also responsible for generating $\mathrm{R} \$$ 12.8 billion in federal, state, and municipal taxes, which corresponds to $0.9 \%$ of the total revenue of the country and for the direct employability of 513,000 people and 3.8 million employability direct and indirect (IBÁ, 2019).

Eucalyptus urograndis is one of the most used clone species in Brazil, a hybrid resulting from the cross between E. grandis and E. urophylla (Paludzyszyn-Filho et al., 2004). This combination resulted in vigorous trees with the wood of greater density and with great resistance to cancer disease caused by the fungus Cryphonectria cubensis (Bruner) Hodges, 1980 (Diaporthales: Cryphonectriaceae) (Paludzyszyn-Filho et al. 2004; Valeri et al. 2001). However, several insects have adapted to Eucalyptus plantations, probably due to the similarity with other Brazilian native plants and homogeneity of the planting that is a constant source of food (Machado et al. 2016; Queiroz et al. 2014). The adaptation occurred for several insect herbivores species, such as leaf-cutting ants (Atta spp. and Acromyrmex spp.), termites of the genera Coptotermes spp. and Heterotermes spp., and the defoliating caterpillars (Eacles imperialis magnifica) (Walker, 1856) (Lepidoptera: Saturniidae); as well as introduced species, such as the bronze bug, Thaumastocoris peregrinus (Carpintero \& Dellapé, 2006) (Hemiptera: Thaumastocoridae), the gall wasps, Epichrysocharis burwelii (Schauff) (Hymenoptera: Eulophidae) and Leptocybe invasa (Fisher \& La Salle) (Hymenoptera: Eulophidae), and the psyllid, Ctenarytaina spatulate (Taylor, 1997) (Hemiptera) (Queiroz et al., 2014).

The Chrysopidae species is among the natural predators used in the biological control of insects and pests in Eucalyptus forests; it is the second-largest family of Neuroptera with 75 genera, 11 subgenera, and 1,200 species (Brooks \& Barnard, 1990). The chrysopids, also called green lacewings, are known as trash-carrier due to the behavior that larvae of many species carry debris on their backs, which gives them protection against natural enemies by the physical barrier and by camouflage. The debris consists of exoskeletons from their prey, fibers of plant or animal origin, and other particles they encounter during their movement, being kept attached to the body 
thanks to the numerous long, smooth, or serrated bristles, with a straight or hook-shaped tip, existing on the dorsal surface and the lateral tubercles of his chest and abdomen (Albuquerque, 2009). Within green lacewing species, Chrysoperla externa (Hagen, 1861) is a predator with wide geographical distribution and a variety of habitats, considered one of the most promising species for biological pest control (Albuquerque et al., 1994; Resende et al., 2017). Besides, the chrysopid posture is readily recognized and easily differentiated from other insects because the eggs are pediceled (Soares et al., 2007). The larvae of $C$. externa have great reproductive and locomotion capacity, tolerance to insecticides, and they can feed on a wide variety of arthropods, including mites and small phytophagous insects, such as aphids (Soares et al., 2007). The knowledge about the life cycle and its assertiveness in the search for prey, adaptation to different climatic conditions, combined with the development of diets and mass creation in the laboratory, reflected in the increased interest of $C$. externa and the Neuroptera group in general for application in biological control programs (Duelli, 2001; Souza \& Carvalho, 2002; Carvalho \& Souza, 2009; Salamanca et al., 2010; Salamanca, 2015).

Thus, to understand the interactions between predatory natural enemies and forest tree species, this study aimed to verify whether the volatiles emitted by young and mature, damaged, and undamaged leaves of $E$. urograndis act attractants of chrysopid larvae. The hypothesis is that there is a preference for chrysopid larvae for the volatiles of young leaves subject to injury, considering that they have a higher production of volatile organic compounds, attracting the predator. Also, was evaluated the essential oil chemical composition of E. urograndis leaves. The hypothesis is that, with the injury, there will be a change in the essential oil composition of young and mature leaves of E. urograndis. With the observations obtained from the experimental analyzes, it will be possible to list the compounds that are attractors or repellents of $C$. externa individuals, resulting in an essential understanding of the behavior of this natural predator used in the biological control of eucalyptus forests.

\section{Methods and Materials}

\section{Plant culture}

Eucalyptus urograndis clones (Urograndis I144 type) were purchased from a plant nursery, "Viveiro Valor Verde" (Araguari, Minas Gerais, Brazil; 18³9'29.3"S and 4809'09.4"W). The experiments were carried out with E. urograndis seedlings with 70 days old, $30 \mathrm{~cm}$ high, and containing from 10 to 12 expanded leaves.

\section{Insect culture}


Chrysoperla externa larvae were obtained from the ALB Agroambiental biofactory (Uberlândia, Minas Gerais, Brazil). The rearing was carried out according to a methodology modified by Macedo \& Soares (2000). In this procedure, the larvae were obtained from adults of $C$. externa, which were collected in the field, sent to the biofactory, and placed in cages. The laboratory environment was maintained under controlled conditions of temperature $\left(25 \pm 2{ }^{\circ} \mathrm{C}\right)$, humidity $(70 \pm 10 \%)$, and using a photoperiod of 14:10 h (light:dark). Plastic cages were prepared from PVC pipe (segments of $23 \mathrm{~cm}$ x $23 \mathrm{~cm}$ ), sealing at the top and bottom with organza fabric. The cage is lined internally with a sheet of A4 paper to allow the removal of the eggs. In each cage were inserted about 12 adult couples of $C$. externa and fed in the upper part through cotton containing an aqueous solution of the yeast and honey. A part of the collected eggs was reserved for the re-start of the rearing cycle of $C$. externa. The other part of the eggs was transferred to a plastic container containing Anagasta kuehniella eggs (Zeller, 1879) (Lepidoptera: Pyralidae) to feed the larvae obtained from $C$. externa eggs. The experiments described below were carried out with larvae of $C$. externa at $7 \pm 2$ days old.

\section{Simulated herbivory treatment}

The simulation of herbivory on E. urograndis leaves was done by artificial damage technic through removing 6 mm leaf discs using a hole punch (P202 model, Tilibra). The experiments were divided into three groups: (1) seedling without damage on leaves; (2) seedling with young leaves with damage: four to five holes in four leaves located at the top of the seedling; and (3) seedling with mature leaves with damage: four to five holes in four leaves located at the bottom of the seedling. A reduction of 10 to $15 \%$ of the area of each leaf was estimated, representing about $1.5 \mathrm{~cm}^{2}$ of total area leaves. Holes were not made in the central rib of the leaves.

\section{Behavioral evaluation using Y-tube olfactometer system}

The evaluation of the olfactory response of C. externa to volatile organic compounds in leaves of the E. urograndis was carried out using a modified model by Akol \& Njagi (2003), Du et al. (1996), and Han \& Chen (2002) (Fig. 1). The tubes with the plants were wrapped with aluminum foil and closed up to the height of the stem, avoiding contamination of the air with the volatile compounds from the plastic of the tube, or from the substrate used to grow the plants, or from the microorganisms present in the substrate (Pinto-Zevallos et al., 2013a,b). The Y-tube olfactometer used presents arms with $2 \mathrm{~cm}$ internal diameter and $17 \mathrm{~cm}$ long at $120^{\circ}$ angle. The airflow in the $\mathrm{Y}$ tube was generated by a vacuum pump (Big Air, A320 model) which went to the activated carbon filter (Planeta Água brand, Fit 200 model) for purification and removal of any impurities. Then, the air passed through a glass 
chamber $(8.5 \mathrm{~cm}$ x $23 \mathrm{~cm})$, where the plants were placed. The entire system was interconnected by PTFE tubes. An airflow of $1.5 \mathrm{~L} \mathrm{~min}^{-1}$ was used in the system and the flow was controlled throw two flow meters (Key Instruments, LPM Air model).

According to the methodology of Resende et al. (2015), a previous study of the displacement of the air inside the Y-tube was carried out using water and dry ice. Our results showed there is no mixing of the air between the different arms. Each bioassay used a larva inserted in the base of the olfactometer. The choice was considered when the larva entered more than $1 / 3$ of the Y-tube arm and remained for 15 seconds. The maximum time established for the bioassay was 10 minutes. Only larvae that chose according to these criteria were considered in the statistical analysis. Four hundred nine bioassays were performed because 280 larvae were used according to the established criteria, and 129 were not considered in the data because they did not respond to the established criteria.

To avoid any positional effects, Y-tube was horizontal turned $180^{\circ}$ (clockwise direction) after each tested larva, and the odors presenting side were changed every three larvae. The Y-tube was changed after six larvae, and every 12 larvae, plants were changed since the production of volatiles can vary between individuals (Pareja et al., 2009). After 12 tests, the Y-tube and the glass chambers were washed with detergent (neutral soap), water, $70 \%$ ethanol and placed in an oven at $100{ }^{\circ} \mathrm{C}$ for 60 minutes. The tests were carried out from 7 am to 5 pm under constant laboratory conditions regarding luminosity (fluorescent light) and temperature $\left(25^{\circ} \mathrm{C}\right)$.

The behavior response of $C$. external larvae to the E. urograndis on the olfactory system was evaluated using 40 larvae in each of the seven combinations as described following (1) clean air in both arms of the olfactometer; (2) plant without damage versus clean air; (3) young leaves with damage versus clean air; (4) mature leaves with damage versus clean air; (5) young leaves with damage versus plant without damage; (6) mature leaves with damage versus plant without damage; and (7) young leaves with damage versus mature leaves with damage.

\section{Data analysis}

The absolute frequency and percentage were used for categorical variables in the description of the results of the olfactometry analysis. The absolute frequency $\left(f_{i}\right)$ is the number of times that a specific variable presents a certain value/category. The percentage $\left(p_{i}\right)$ is the result of the ratio between the absolute frequency and the sample size, multiplied by 100 . To check if there were significant differences in the percentage of choice between the alternatives of each olfactometry test, the chi-square test $\left(\chi^{2}\right)$ was applied, considering the expected proportion of 
$0.50(50 \%)$ in each of the arms of the Y-tube olfactometer. The analyzes were performed in the statistical environment R Development Core Team (version 3.3.1) with a significance level of 5\% (Aboubakar Souna et al., 2019).

\section{Essential oil extraction}

Essential oil (EO) was extracted from the leaves of E. urograndis. These leaves were separated into four groups: young leaves without damage, young leaves with damage, mature leaves without damage, and mature leaves with damage. All leaves were damaged moments before the oil was extracted. Initially, the moisture content of each group of leaves was measurement by the gravimetric method using an infrared moisture determination balance (Quimis, model Kett FD-600). The method was done with $1.0 \mathrm{~g}$ of leaves at a temperature of $105 \pm 5^{\circ} \mathrm{C}$ for $15 \mathrm{~min}$. The extraction of the EO from each group of leaves was carried out in a Clevenger apparatus, by hydrodistillation, under reflux for 4 hours with $50 \mathrm{~g}$ of fresh leaves (Silva et al., 2020). The extraction was carried out in triplicate. The EO was extracted from water with dichloromethane (Vetec, RJ, Brazil) (3 x $10 \mathrm{~mL})$. The solvent was removed by evaporation in a heating plate at $35^{\circ} \mathrm{C}$. Essential oils obtained were stored in glass bottles, sealed, and kept in a refrigerated environment in the absence of light.

\section{Essential oil chemical composition}

The composition of EOs was identified by a gas chromatograph coupled to a mass spectrometer (GC-MS) (Shimadzu, QP2010 model) using a DB-5 capillary column (J\&W, $30 \mathrm{~m} \times 0.25 \mathrm{~mm} \times 0.25 \mathrm{~m})$. The samples of EOs were solubilized in dichloromethane at $5 \mathrm{mg} \mathrm{mL}^{-1}$. The conditions used were: helium as a carrier gas with a constant flow of $1.02 \mathrm{~mL} \mathrm{~min}^{-1}$; injector temperature of $240{ }^{\circ} \mathrm{C}$; detector temperature of $220{ }^{\circ} \mathrm{C}$; splitless mode of injection (1:10); oven temperature programmed from $60{ }^{\circ} \mathrm{C}$ and increase to $246{ }^{\circ} \mathrm{C}$ at $3{ }^{\circ} \mathrm{C} \min ^{-1}$, maintained for $38 \mathrm{~min}$; the ionizing potential of $70 \mathrm{eV}$; a range of $\mathrm{m} / \mathrm{z}$ 40-650. The compound identification of the EO was based on the similarity index (SI) obtained by the software (LabSolution-GC-MS Solution) with the mass spectral commercial libraries Nist27, Nist147, Wiley7, Wiley229, and Shim2205 libraries. Arithmetic index (AI) was also used to identify compounds about standard alkanes (Adams 2007). The AI was calculated using the equation: AI $(\mathrm{x})=100 \mathrm{C}(\mathrm{Pz})+100[(\mathrm{RT}(\mathrm{x})-\mathrm{RT}(\mathrm{Pz})) /(\mathrm{RT}(\mathrm{Pz}+1)-\mathrm{RT}(\mathrm{Pz}))]$, in which $\mathrm{RT}$ is the retention time in min, $\mathrm{x}$ is an unknown compound, $\mathrm{C}$ is the carbon number of the alkane $\mathrm{Pz}$ that runs before $\mathrm{x}$, and $\mathrm{Pz}+1$ is the alkane that runs after $\mathrm{x}$. The AI obtained was compared with AIs of the Webbook-NIST Standard Reference Data (Wallace, 2018) and the Adams book (Adams, 2007). 


\section{Results}

\section{Olfactometry tests}

The results obtained with the choices of $C$. externa larvae in each olfactometry test performed with $E$. urograndis leaves are shown in Fig. 2. The results of the Chi-square test are listed in Table 1. In the treatment in which clean air was offered on both sides of the Y-tube olfactometer, the larvae randomly chose both the left and right sides, and there was no significant difference $\left(\chi^{2}=0.63 ; p=0.429\right)$. When opposed to clean air, the larvae preferred the volatile compounds of the plants without damage $\left(\chi_{1}^{2}=7.23 ; p=0.007\right)$ and the plants with young leaves with damage $\left(\chi^{2}=11.03 ; p=0.001\right)$. The frequency of choice of the larvae on one side of the Y-tube was more than $70 \%$ in these tests. However, the seedlings with mature leaves damage, although chosen more frequently about clean air (57.5 versus $42.5 \%)$, did not show any significant difference $\left(\chi^{2}=0.63 ; p=0.429\right)$. There was also no significant predominance of the preference of larvae for the plants with young leaves with damage $\left(\chi^{2}=\right.$ 3.02; $p=0.082)$ or mature leaves with damage $\left(\chi^{2}=2.03 ; p=0.155\right)$ when opposed to the plant without damage. Therefore, although not significant, the percentage of choice of larvae for the plants without damage (62.5 $\%)$ was higher than the plants with mature leaves with damage (37.5\%). There was also a predominance of choice of the larvae for the plants with young leaves with damage $(80 \%)$ in comparison to the plants with mature leaves with damage $(20 \%)$, showing a significant difference $\left(\chi^{2}=13.23 ; p<0.001\right)$.

\section{Essential oil extraction}

The extraction yield and the amount of EO of E. urograndis leave obtained by hydrodistillation are shown in Table 2. The yield obtained in this study ranged from $0.29 \%$ for mature leaves up to $0.50 \%$ for young leaves.

\section{Essential oil chemical composition}

The chemical composition of EOs from each group of leaves of the E. urograndis was determined by CG-MS. The chromatogram profiles (Fig. S1) showed 42 peaks which are was possible to identify 32 compounds. The AI of the identified compounds of EO is showed in Table S1. Table 3 shows the percentage of the identified compounds by total ion chromatogram. Figure 3 shows the structures of the compounds identified, and $69 \%$ of them are monoterpenes oxygenated, and $22 \%$ are oxygenated sesquiterpenes. Eucalyptol, Linalool, Borneol, $\alpha-$ Terpineol, Neral, Carvone, Geraniol, and $\alpha$-Terpinyl acetate are the major oxygenated monoterpenes. Alpha- 
copaene, Aromadendrene, Spathulenol, Caryophyllene oxide, Globulol, and Viridiflorol are the major sesquiterpenes.

According to Table 3, compounds 1, 11, 21, and 36 presented the highest concentrations in all EO's. There was a higher concentration of Spathulenol (36) $(12.20 \%)$ in the EO of young leaves with damage than Eucalyptol (1) (10.36\%) and $\alpha$-Terpineol (11) (11.9\%). Essential oils of the mature leaves with damage presented $12.37 \%$ of Spathulenol (36), a result higher than that of Eucalyptol (7.59\%) (1). However, the chromatogram analysis indicated that this peak is a mixture of Spathulenol with Caryophyllene oxide and Globulol; they are all oxygenated sesquiterpenes. The sum of these compounds is representative, as it amounts to almost $50 \%$ of the mass of EO.

Table 4 shows the percentage variation of the main compounds in the EOs of young and mature leaves with damage from E. urograndis. Compounds 28 and 42, although having a low concentration of TIC, are among the sixteen main compounds identified as they make up about $80 \%$ of the composition of the EOs of E. urograndis. These two compounds showed a significant change in their percentage of composition in the EO from the damaged leaf. It was observed that the EOs of young and mature leaves with damage showed an increase in the concentration of these compounds concerning leaves without damage. Essential oils of damaged leaves demonstrated a rise in both productions of $\alpha$-Terpineol (11) (9.6 and $19.5 \%$ for young and mature leaves, respectively) and $\alpha$-Terpinyl acetate (21) (47.9 and $25 \%$ for young and mature leaves, respectively).

In contrast, there was observed a significant drop in Eucalyptol (1) production (-63.2 and -62.7 \% or young and mature leaves, respectively) in the EOs from leaves with damage. Essential oils of damaged young leaves resulted in an increase of $50.0 \%$ in Aromadendrene (28) and $39.7 \%$ in 5-Hydroxy-isobornyl-isobutanoate (42). Essential oils of mature damaged leaves resulted in a rise of $44.9 \%$ in Aromadendrene (28) and a reduction of $24.8 \%$ in 5-Hydroxy-isobornyl-isobutanoate (42).

\section{Discussion}

\section{Herbivory simulation and olfactometry tests}

In all analyzes carried out, although the sources of odor and the arms of the olfactometer were inverted to avoid any bias, an additional test was carried out with the provision of clean air in both arms. The result of this test demonstrated that there was no defect on either side of the olfactometer, proving the efficiency of the system and corroborating the results of other studies that used a similar methodology. Tests of this nature are commonly performed in experiments with an olfactometer system to ensure that no bias occurs, as an example, Blassioli- 
Moraes et al. (2005) evaluated the response of the parasitoid Telenomus podisi (Ashmead) (Hymenoptera: Scelionidae) to the volatiles of soybean seeds Glycine max (L.) Merrill and nymphs of Euschistus heros (F.) (Heteroptera: Pentatomidae).

Our results demonstrated that $C$. externa larvae have a behavior of choice when in contact with volatile organic compounds of E. urograndis, corroborating other studies that used Chrysoperla species as a model. For instance, Salamanca et al. (2015) demonstrated the attraction of adults of $C$. externa to the volatiles of the Coriandrum sativum L. (Apiaceae) when isolated and in the presence of flowers of Rosa hybrida L. (Rosaceae). Resende (2012) found that unmated and mated adults of C. externa had different choices to the volatile coriander and fennel Foeniculum vulgare Mill. According to this author, unmated adults (males and females) were attracted to coriander, whereas mated ones were attracted to fennel. In a study by Zhu et al. (2005), Chrysoperla carnea and Chrysopa oculata Say (Neuroptera: Chrysopidae) had different choices when in contact with volatiles of the alfalfa (Medicago sativa $\mathrm{L}$ ) and pheromones from the aphid Acyrthosiphon pisum Harris (Hemiptera: Aphididae). In this study, C. carnea was attracted by the volatiles of alfalfa and C. oculata by the volatiles of the aphid. Reddy (2002) identified the preference of adults of $C$. carnea to the volatile leaves of eggplant (Solanum melongena L., Solanaceae), okra (Abelmoschus esculents L., Malvaceae), and pepper (Capsicum annum L., Solanaceae) subject to artificial mechanical damage.

In our study, only the insect predator and the plant were used to identify the role of volatiles in the plantpredator interactions. The results found here corroborate with other studies mentioned above since the larvae of C. externa made choices according to the different types of volatiles of the $E$. urograndis, without the participation of prey and other elements. According to Hogervorst et al. (2008), Limburg \& Rosenheim (2001), and Takabayashi \& Shiojiri (2019), predators respond to the chemical clues emitted by plants both for locating their prey and for the consumption of elements produced by plants to supplement their diet, like "honeydew" and extrafloral nectar. Ananthakrishnan (1992) reports that a natural enemy can recognize the factors of the host plant and that the decision to choose foraging in the plant is made regardless of the presence or absence of its prey or host.

The olfactometry tests indicated a variation between the volatiles emitted by young and mature leaves, corroborating with Boege \& Marquis (2005). These authors suggest an inverse relationship between age and the production of indirect defenses by plants, resulting in changes in the interactions between plants, herbivores, and their natural enemies throughout the development of plant structures. Several other studies corroborate the difference between volatile organic compounds according to the ontogenetic stage of the leaves (Bracho-Nunez et al., 2011; Cole, 1980; Li et al., 1996; Maatallah et al., 2020). The damage caused on the young and mature leaves 
triggered different responses of the larvae of C. externa, with preference to the odors emitted by young leaves. Other studies also report the preference of insects for odors of young leaves due to aspects related to oviposition and nutrition (Nahrung \& Allen, 2003; Tanaka \& Nakasuji, 2002).

\section{Essential oil extraction}

About 17,500 aromatic species of higher plants, mainly from the Myrtaceae, Lauraceae, Lamiaceae, and Asteraceae families, produce essential oils (Regnault-Roger et al., 2012). Among the species of the Myrtaceae family, the genus Eucalyptus has more than 200 species with essential oil production in its leaves (Pino et al., 2002; Vitti \& Brito, 2003) but less than 20 are exploited industrially (Lu et al., 2016). One of them is E. urograndis and is not included in the list of the main species of eucalyptus used to produce essential oil, probably because they do not have sufficient extraction yield to justify the commercial exploitation of their essential oil. Pereira (2010) collected leaves at random points in the crown of adult individuals of E. urograndis and found a yield of $1.56 \%$. The result found by this author was expressive when compared to the three species with the highest yield in Brazil, E. citriodora Hook, E. globulus Labill, and E. staigeriana F.Muell, with 1-1.6, 1.7-2, and 1.4 \%, respectively (Vitti \& Brito, 2003). However, other studies have yield results similar to those found in this study for the mature leaves. Goldbeck et al. (2014) used leaves from the canopy of E. urograndis individuals of 19 months old and found a $0.29 \%$ yield for the essential oil extraction. Bonora (2016) evaluated mature leaves of $E$. urograndis and found a $0.20 \%$ yield.

In our study, the yield found for the essential oil of mature leaves of E. urograndis is not high compared to other eucalyptus species. In contrast, the essential oil yield of young leaves was considered moderate, according to other studies. Silva et al. (2006) evaluated the yield of 11 Eucalyptus species, with E. citriodora, E. viminalis Labill, and E. globulus achieving the best results, 1.70, 1.56, and $1.07 \%$; the worst results were found for E. pellita F. Muell and E. cloeziana F. Muell, being $0.00 \%$ and $0.12 \%$, respectively. In an evaluation of essential oils from 12 Eucalyptus species, Bonora (2016) found higher yields in E. staigeriana F. Muell and E. citriodora, with 1.6 and $1.3 \%$, respectively, and lower yields in Corymbia ptychocarpa F. Muell and E. saligna Smith, with 0.021 and $0.11 \%$, respectively.

Regarding the influence of the age of the E. urograndis leaves on the production of essential oil, there is still no clear trend, and further studies are needed to clarify the theme (Vitti and Brito 2003). In this sense, the results of this study have a significant contribution, since variation in yield and greater production of essential oil 
was found in young leaves, corroborating with studies by Silvestre et al. (1997) and Li et al. (1994), who found the higher yield of essential oil in young leaves of E. globulus and E. nitens H. Deane \& Maiden, respectively.

\section{Essential oil chemical composition}

In our study, 32 compounds were identified by GC-MS analysis, which is higher than other studies, such as Goldbeck et al. (2014), Bonora (2016), Araújo et al. (2010), and Pereira (2010), who identified 21, 17, 10 and 10 compounds, respectively. This variation in the identification between the studies is due to the differences in the extraction methodology as well as in the plants used in the analysis because according to Darrow \& Bowers (1997), despite the existence of genetic control, the variations of season, day, intra-plant, inter-plant, and intraspecific can influence the total content and proportions of plant secondary metabolite compounds.

Araújo et al. (2010) and Goldbeck et al. (2014) found a predominance of oxygenated monoterpenes and oxygenated sesquiterpenes in their essential oil studies E. urograndis leaves, corroborating the results found in this study. Vitti \& Brito (2003) also report the predominance of terpenic compounds - mono and sesquiterpenes in essential oils. According to Harbone (1991), these compounds are related to plant metabolism functions, which can be found in hormones, membrane structures, and according to Andrew et al. (2013), Lawler et al. (1999), and Marsh et al. (2006), they are important in direct and indirect interactions with herbivores and other organisms.

The predominance of Eucalyptol, $\alpha$-Terpineol, and $\alpha$-Terpinyl acetate found in this study agrees with the results of Bonora (2016). This study was carried out with mature leaves of E. urograndis, and the compounds previously mentioned had a higher concentration (Eucalyptol, $\alpha$-Terpineol, and $\alpha$-Terpinyl acetate with $17.7,17.8$, and $15.6 \%$, respectively). This variation between compounds is also corroborated by Dellacassa \& Moyna (1992), who clarifies that the existence of qualitative variations among individuals of the same species is common due to genetic, environmental, type of leaves selected and differences in extraction techniques and equipment used in the analysis of essential oils.

The olfactometry tests demonstrated that the leaves of E. urograndis responded to simulated herbivory by changing the concentration of the compounds in its essential oil, corroborating with Turlings et al. (1990). Also, such response influenced the behavior of $C$. externa, following Turlings \& Wackers (2004) when stating that behavioral observations and chemical analyses strongly suggest that the induced volatiles of plants plays a fundamental role in the location of the host or prey by natural enemies.

The results of this research demonstrate a preference for $C$. externa over the odor of young leaves with damage of E. urograndis (Table 1). Considering only the variation of the compounds Eucalyptol, $\alpha$-Terpineol and 
$\alpha$-Terpinyl acetate after the damage in young and mature leaves shown in Table 4 , there is an inversion in the concentration between Eucalyptol (which decreases) and $\alpha$-Terpinyl acetate (which increases) with the damage caused to the leaf, whether young or mature. Besides, observing Table 2, the essential oil content of young leaves is higher than the mature leaves. From this, an important observation can be highlighted, the content of volatile compounds may have influenced the attraction of $C$. externa since when there are options between clean air and volatiles, the $C$. externa larvae prefer the volatiles. The higher the volatile content, the greater the attraction. Therefore, in the test of choice between young and mature leaves with damage, the $C$. externa larvae prefer young leaves with damage. Also, another important observation must be highlighted, the inversion observed in the content of Eucalyptol (which decreases) and $\alpha$-Terpinyl acetate (which increases) may be due to the damage caused to the leaves since this was observed in young and mature leaves. This damage may have influenced the biosynthesis of $\alpha$-Terpinyl acetate, a more volatile compound than Eucalyptol. From the observation of the larva choice (Fig. 1) between young leaves with damage and young and mature leaves without damage, it is verified the preference of the larvae for the volatiles emitted by the young leaves with damage. This shows that something different may be present in the volatiles that acted as major attractors of $C$. externa larvae. The inversion is in the content between Eucalyptol (which decreases), and $\alpha$-Terpinyl acetate (which increases) may justify this behavior of C. externa. These results contribute to identifying the potential use of eucalyptus forests as natural maintainers of $C$. externa populations.

Acknowledgments To the Graduate Program in Ecology and Conservation of Natural Resources of the Federal University of Uberlandia that allowed this study to be carried out. To the Laboratory of Ecology and Biodiversity (LEBIO) of the Federal University of Sergipe and the Laboratory of the Nucleus for Research in Natural Products (NuPPeN), the Institute of Chemistry from the Federal University of Uberlandia that provided the adequate structure for the realization of research.

Funding This research was supported by grants from FAPEMIG, grant numbers APQ-02342-18, APQ-01392-14 and APQ-02481-14 awarded to R.M.F.S., A.O. and M.P., respectively, and federal funding agency Conselho Nacional de Desenvolvimento Científico e Tecnológico (CNPq), grant number 449846/2014-8, awarded to M.P. and grant number to $312752 / 2018-0$, awarded to J.C.S. This study was financed in part by the Coordenação de Aperfeiçoamento de Pessoal de Nível Superior - Brasil (CAPES) - Finance Code 001. The authors thank Ricardo 
Reis Soares for GC-MS equipment, and to the Coordenação de Aperfeiçoamento de Pessoal de Nível Superior (CAPES) for scholarships.

Conflicts of interest/Competing interests The authors have no conflicts of interest to declare relevant to the content of this article.

Ethics approval Not applicable.

Consent to participate Not applicable.

Consent for publication The authors consent to the publication of the article and its data in this journal.

Availability of data and material Data are not openly accessible.

Code availability Not applicable.

Author contributions David J. V. Borges: Methodology, CG-MS analysis, Writing - original draft. Rafael A. C. Souza: Methodology, CG-MS analysis, Writing - original draft. Alberto de Oliveira: Funding acquisition, Supervision, Conceptualization, Writing - review \& editing. Raquel M. F. Sousa: Funding acquisition, Supervision, Conceptualization, Writing - review \& editing. Jean C. Santos: Funding acquisition, Supervision, Conceptualization, Writing - review \& editing. 


\section{References}

Aboubakar Souna D et al. (2019) Volatiles from Maruca vitrata (Lepidoptera, Crambidae) host plants influence olfactory responses of the parasitoid Therophilus javanus (Hymenoptera, Braconidae, Agathidinae). Biol Control 130:104-109. doi: 10.1016/j.biocontrol.2018.11.002

Adams RP (2007) Identification of essential oil components by gas chromatography/quadrupole mass spectroscopy. 4th edn. Allured Bussiness Media, Carol Stream

Akol AM, Njagi PGN, Sithanantham S, Mueke JM (2003) Effects of two neem insecticide formulations on the attractiveness, acceptability and suitability of diamondback moth larvae to the parasitoid, Diadegma mollipla (Holmgren) (Hym., Ichneumonidae). J Appl Entomol 127:325-331. doi:10.1046/j.14390418.2003.00771.x

Albuquerque G, Tauber C, Tauber M (1994) Chrysoperla externa (Neuroptera: Chrysopidae): life history and potential for biological control in Central and South America. Biol Control 4:8-13

Albuquerque GS (2009) Crisopídeos (Neuroptera: Chrysopidae). In: Panizzi AR, Parra JRP (eds) Bioecologia e Nutrição de Insetos: Base Para o Manejo Integrado de Pragas. Embrapa Informação Tecnológica, Brasília, pp 969-1022

Ananthakrishnan TN (1992) Chemical ecology in biological control. In: Ananthakrishnan TN (ed) Emerging Trends in Biological Control of Phytophagous Insects. Oxford and IBH Publishing, New Delhi, pp 59-67

Andrew RL, Keszei A, Foley WJ (2013) Intensive sampling identifies previously unknown chemotypes, population divergence and biosynthetic connections among terpenoids in Eucalyptus tricarpa.

Phytochemistry 94:148-158 doi:10.1016/j.phytochem.2013.05.002

Araújo FOLd, Rietzler AC, Duarte LP, Silva GDdF, Carazza F, Vieira Filho SA (2010) Constituintes químicos e efeito ecotoxicológico do óleo volátil de folhas de Eucalyptus urograndis (Mirtaceae). Quim Nova 33:1510-1513 doi:10.1590/S0100-40422010000700016

Blassioli-Moraes MC, Laumann R, Sujii E, Pires C, Borges M (2005) Induced volatiles in soybean and pigeon pea plants artificially infested with the Neotropical brown stink bug, Euschistus heros, and their effect on the egg parasitoid, Telenomus podisi. Entomol Exp Appl 115:227-237 doi:10.1111/j.15707458.2005.00290.x

Boege K, Marquis RJ (2005) Facing herbivory as you grow up: the ontogeny of resistance in plants Trends Ecol Evol 20:441-448 doi:10.1016/j.tree.2005.05.001

Bonora FS (2016) Prospecção de compostos químicos presentes nos óleos essenciais das folhas e flores de eucalipto. Dissertação de Mestrado Universidade de São Paulo, Piracicaba, SP 
Bracho-Nunez A, Welter S, Staudt M, Kesselmeier J (2011) Plant-specific volatile organic compound emission rates from young and mature leaves of Mediterranean vegetation. J Geophys Res 116: D16304:1-13 doi:10.1029/2010JD015521

Brooks SJ, Barnard PC (1990) The green lacewings of the world: a generic review (Neuroptera: Chrysopidae) Bulletin of the British Museum (Natural History) 59:117-286

Carvalho CF, Souza B (2009). Métodos de criação e produção de crisopídeos. In: Bueno, V.H.P. (Ed.), Controle biológico de pragas: produção massal e controle de qualidade. UFLA, Lavras, pp. 77-115.

Cole RA (1980) Volatile components produced during ontogeny of some cultivated crucifers. J Sci Food Agric 31:549-557 doi:10.1002/jsfa.2740310606

Darrow K, Bowers MD (1997) Phenological and population variation in iridoid glycosides of Plantago lanceolata (Plantaginaceae). Biochem Syst Ecol 25:1-11 doi:10.1016/S0305-1978(96)00090-7

Dellacassa E, Moyna P (1992) Eucalyptus leaf oils, use, chemistry, distillation and marketing. Inkata Press, Melbourne.

Du YJ, Poppy GM, Powell W (1996) Relative importance of semiochemicals from first and second trophic levels in host foraging behavior of Aphidius ervi. J Chem Ecol 22:1591-1605 doi:10.1007/BF02272400

Duelli P (2001). Lacewings in field crops. In: McEwen, P.K., New, T.R., Whittington, A.E. (Eds.), Lacewings in the Crop Environment. Cambridge University Press, Cambridge, pp. 158-164.

Goldbeck J, Nascimento J, Jacob R, Fiorentini A, Silva W (2014) Bioactivity of essential oils from Eucalyptus globulus and Eucalyptus urograndis against planktonic cells and biofilms of Streptococcus mutans. Ind Crops Prod 60:304-309 doi:10.1016/j.indcrop.2014.05.030

Han B, Chen Z (2002) Behavioral and Electrophysiological Responses of Natural Enemies to Synomones from Tea Shoots and Kairomones from Tea Aphids, Toxoptera aurantii. J Chem Ecol 28:2203-2219 doi:10.1023/A:1021045231501

Harborne JB (1991) Recent advances in the ecological chemistry of plant terpenoids. In: Harborne JB, TomasBarberan FA (eds) Ecological Chemistry and Biochemistry of Plant Terpenoids. University Press, Oxford, pp 399-426

Hogervorst PAM, Wäckers FL, Carette A-C, Romeis J (2008) The importance of honeydew as food for larvae of Chrysoperla carnea in the presence of aphids. J Appl Entomol 132:18-25 doi:10.1111/j.1439-

0418.2007.01247.x 
IBÁ (2019) Relatório Anual 2019. https://iba.org/datafiles/publicacoes/relatorios/iba-relatorioanual2019.pdf. Accessed 26.012020

Júnior JEP, Santarosa E, Goulart ICGR (2014) Histórico do cultivo do Eucalipto. In: Júnior JEP, Santarosa E, Goulart ICGR (eds) Transferência de tecnologia florestal: cultivo de eucalipto em propriedades rurais: diversificação da produção e renda. Embrapa, Brasília, pp 11-12

Lawler IR, Stapley J, Foley WJ, Eschler BM (1999) Ecological Example of conditioned flavor aversion in plantherbivore interactions: Effect of terpenes of Eucalyptus leaves on feeding by common ringtail and brushtail possums. J Chem Ecol 25:401-415 doi:10.1023/A:1020863216892

Li H, Madden JL, Davies NW (1994) Variation in leaf oils of Eucalyptus nitens and E. denticulata. Biochem Syst Ecol 22:631-640 doi:10.1016/0305-1978(94)90076-0

Li H, Madden JL, Potts BM (1996) Variation in volatile leaf oils of the Tasmanian Eucalyptus species II. Subgenus Symphyomyrtus. Biochem Syst Ecol 24:547-569 doi:10.1016/0305-1978(96)00040-3

Lu, H., Shao, X., Cao, J., Ou, C., \& Pan, D. (2016). Antimicrobial activity of eucalyptus essential oil against Pseudomonas in vitro and potential application in refrigerated storage of pork meat. Int J Food Sci Technol 51:994-1001 doi: 10.1111/ijfs.13052.

Limburg D, Rosenheim J (2001) Extrafloral nectar consumption and its influence on survival and development of an omnivorous predator, larval Chrysoperla plorabunda (Neuroptera: Chrysopidae) Environ Entomol 30:595-604 doi:10.1603/0046-225X-30.3.595

Maatallah S, Dabbou S, Castagna A, Guizani M, Hajlaoui H, Ranieri AM, Flamini G (2020) Prunus persica byproducts: A source of minerals, phenols and volatile compounds. Sci Hortic 261:109016 doi:10.1016/j.scienta.2019.109016

Macedo LPM, Soares JJ (2000) Criação de Chrysoperla externa para o controle biológico de pragas do algodoeiro. EMBRAPA-CNPA Circular Técnica, 36:1-9

Machado D, Costa E, Garlet J, Boscardin J, Pedron L, Perini C, Bolzan L (2016) Avaliação de Inseticidas no Controle de Thaumastocoris peregrinus (Hemiptera: Thaumastocoridae) Percevejo-bronzeado em Condições de Laboratório Floresta e Ambiente 32:245-260 doi:10.1590/2179-8087.144415

Marsh KJ, Wallis IR, McLean S, Sorensen JS, Foley WJ (2006) Conflicting demands on detoxification pathways influence how common brushtail possums choose their diets. Ecology 87:2103-2112 doi:10.1890/00129658(2006)87[2103:cdodpi]2.0.co;2 
Nahrung HF, Allen GR (2003) Intra-plant host selection, oviposition preference and larval survival of Chrysophtharta agricola (Chapuis) (Coleoptera: Chrysomelidae: Paropsini) between foliage types of a heterophyllous host. Agric Forest Entomol 5:155-162 doi:10.1046/j.1461-9563.2003.00172.x

Paludzyszyn-Filho E, Pacheco AR, Dittmar H, Cordeiro CA (2004) Estratégias para o melhoramento de eucaliptos tropicais na Embrapa Colombo: Embrapa Florestas:24

Pareja M, Mohib A, Birkett MA, Dufour S, Glinwood RT (2009) Multivariate statistics coupled to generalized linear models reveal complex use of chemical cues by a parasitoid. Anim Behav 77:901-909 doi:10.1016/j.anbehav.2008.12.016

Pereira JL (2010) Composição química dos óleos essenciais de espécies de Eucalyptus L Herit (Myrtaceae). Dissertação de Mestrado Universidade Federal de Viçosa, Viçosa, MG

Pino JA, Marbot R, Quert R, García H (2002). Study of essential oils of Eucalyptus resinifera Smith, E. tereticornis Smith and Corymbia maculata (Hook.) KD Hill \& LAS Johnson, grown in Cuba. Flavour Fragr J 17:1-4 doi: 10.1002/ffj.1026

Pinto-Zevallos DM, Hellén H, Hakola H, van Nouhuys S, Holopainen JK (2013a) Induced defenses of Veronica spicata: Variability in herbivore-induced volatile organic compounds Phytochem Lett 6:653-656 doi:10.1016/j.phytol.2013.08.015

Pinto-Zevallos DM, Martins CBC, Pellegrino AC, Zarbin PHG (2013b) Compostos orgânicos voláteis na defesa induzida das plantas contra insetos herbívoros. Quim Nova 36:1395-1405 doi:10.1590/S010040422013000900021

Queiroz DL, Barbosa LR, Iede ET (2014) Principais pragas e seu controle. In: Santarosa E, Junior JFP, Goulart ICGDR (eds) Transferência de tecnologia florestal: cultivo de eucalipto em propriedades rurais: diversificação da produção e renda. Embrapa, Brasília, pp 87-102

Reddy G (2002) Plant volatiles mediate orientation and plant preference by the predator Chrysoperla carnea Stephens (Neuroptera: Chrysopidae). Biol Control 25:49-55 doi:10.1016/S1049-9644(02)00038-5

Regnault-Roger C, Vincent C, Arnason JT (2012). Essential oils in insect control: low-risk products in a highstakes world. Annu Rev Entomol 57:405-424 doi: 10.1146/annurev-ento-120710-100554

Resende ALS (2012) Bioecologia de Chrysoperla externa (Hagen, 1861) (Neuroptera: Chrysopidae) e análise faunística da artropodofauna associada a plantas da família Apiaceae. Tese de Doutorado, Universidade Federal de Lavras, Lavras, MG 
Resende ALS, Ferreira RB, Souza Bg (2015) Atratividade de adultos de Chrysoperla externa (Hagen, 1861) aos compostos voláteis de coentro, endro e erva-doce (Apiaceae) em condições de laboratório. Revista Ceres 62:37-43 doi:10.1590/0034-737X201562010005

Resende ALS, Souza B, Ferreira RB, Aguiar-Menezes EL (2017) Flowers of Apiaceous species as sources of pollen for adults of Chrysoperla externa (Hagen) (Neuroptera). Biol Control 106:40-44 doi:10.1016/j.biocontrol.2016.12.007

Salamanca J, Varón DEH, Santos AO (2010). Cría y evaluación de la capacidad de depredación de Chrysoperla externa sobre Neohydatothrips signifer, trips plaga del cultivo de maracuyá. Corp Cien Tecnol Agropecu 11:31-40 doi:10.21930/rcta.vol11_num1_art:192

Salamanca J, Pareja M, Rodriguez-Saona C, Resende ALS, Souza B (2015) Behavioral responses of adult lacewings, Chrysoperla externa, to a rose-aphid-coriander complex. Biol Control 80:103-112 doi:10.1016/j.biocontrol.2014.10.003

Santarosa E, Junior JEP, Goulart ICGR, Penteado-Junior JF (2014) Importância socioeconômica e principais usos do eucalipto. In: Santarosa E, Junior JEP, Goulart ICGR, Penteado-Junior JF (eds) Transferência de tecnologia florestal: cultivo de eucalipto em propriedades rurais: diversificação da produção e renda. Embrapa, Brasília, pp 13-22

Silva MVSG et al. (2020) Essential oil from leaves of Eugenia calycina Cambes: Natural larvicidal against Aedes aegypti. J Sci Food Agric doi:https://doi.org/10.1002/jsfa.10732

Silva PHMd, Brito JO, Silva Junior FGd (2006) Potential of eleven Eucalyptus species for the production of essential oils Scientia Agricola 63:85-89 doi:10.1590/S0103-90162006000100014

Silvestre AJD, Cavaleiro JS, Delmond B, Filliatre C, Bourgeois G (1997) Analysis of the variation of the essential oil composition of Eucalyptus globulus Labill. from Portugal using multivariate statistical analysis Ind Crops Prod 6:27-33 doi:10.1016/S0926-6690(96)00200-2

Soares JJ, Do Nascimento ARB, Da Silva MV (2007) Informações sobre Chrysoperla externa. Embrapa Algodão. Documentos. https://ainfo.cnptia.embrapa.br/digital/bitstream/CNPA/21100/1/DOC175.PDF. Accessed 20.102020

Souza B, Carvalho CF (2002). Population dynamics and seasonal occurrence of adults of Chrysoperla externa (Hagen, 1861) (Neuroptera: Chrysopidae) in a citrus orchard in Southern Brazil. Acta Zool Academ Sci Hung 48:301-310. 
Takabayashi J, Shiojiri K (2019) Multifunctionality of herbivory-induced plant volatiles in chemical communication in tritrophic interactions. Curr Opin Insect Sci 32:110-117 doi:10.1016/j.cois.2019.01.003

Tanaka M, Nakasuji F (2002) Dynamic interaction between a leaf beetle, Galerucella nipponensis, and an aquatic plant, Trapa japonica. II. Dispersal behavior of larvae. Popul Ecol 44:1-6 doi:10.1007/s101440200000

Turlings T, Tumlinson J, Lewis W (1990) Exploitation of herbivore-induced plant odors by host-seeking parasitic wasps. Science 250 doi:10.1126/science.250.4985.1251

Turlings TCJ, Wackers F (2004) Recruitment of predators and parasitoids by herbivore-injured plants. In: Cardé RT, Millar JG (eds) Advances in Insect Chemical Ecology. Cambridge University Press, Cambridge, pp 21-75. doi:10.1017/CBO9780511542664.003

Valeri SV, Ferreira ME, Martins MIEG, Banzatto DA, Alvarenga SF, Corradini L, Do Valle CF (2001) Recuperação de povoamento de Eucalyptus urophylla com aplicações de nitrogênio, potássio e calcário dolomítico. For Sci 60:53-71

Vitti AMS, Brito OJ (2003) Óleo essencial de eucalipto. ESALQ, Piracicaba

Wallace WE (2018) Retention Indices. In: Linstrom PJ, Mallard WG (eds) NIST Mass Spectrometry Data Center, vol 2018. vol 17 March 2018. National Institute of Standards and Technology, Gaithersburg. doi:https://doi.org/10.18434/T4D303

Zhu J, Obrycki J, Ochieng S, Baker T, Pickett J, Smiley D (2005) Attraction of two lacewing species to volatiles produced by host plants and aphid prey. Die Naturwissenschaften 92:277-281 doi:10.1007/s00114-0050624-2 


\section{Tables}

Table 1. Difference tests of the percentage of choice for the treatment of the olfactometer. ${ }^{*} p<0.05$.

\begin{tabular}{|c|c|c|c|}
\hline \multicolumn{2}{|c|}{ Olfactometer treatment } & \multicolumn{2}{|c|}{ Chi-square test } \\
\hline Left & Right & $\chi^{2}$ & $p$-value \\
\hline Clean air & Clean air & 0.63 & 0.429 \\
\hline Young and mature leaves without damage & Clean air & 7.23 & $0.007 *$ \\
\hline Young leaves with damage & Clean air & 11.03 & $0.001 *$ \\
\hline Mature leaves with damage & Clean air & 0.63 & 0.429 \\
\hline Young leaves with damage & $\begin{array}{c}\text { Leaves young and mature without } \\
\text { damage }\end{array}$ & 3.02 & 0.082 \\
\hline Mature leaves with damage & $\begin{array}{l}\text { Leaves young and mature without } \\
\text { damage }\end{array}$ & 2.03 & 0.155 \\
\hline Young leaves with damage & Mature leaves with damage & 13.23 & $<0.001^{*}$ \\
\hline
\end{tabular}


Table 2. Essential oil (EO) content from E. urograndis leaves by hydrodistillation method.

\begin{tabular}{lcccc}
\hline Samples & Mass $(\mathbf{g})$ & $\begin{array}{c}\text { Moisture } \\
\text { content }(\boldsymbol{\%})\end{array}$ & EO (mg) & Yield (\%) \\
\hline Young leaves without damage & $50.0 \pm 0.2$ & $60.7 \pm 2.42$ & $99.5 \pm 0.3$ & $0.50 \pm 0.02$ \\
Young leaves with damage & $50.0 \pm 0.2$ & $60.7 \pm 2.42$ & $100.4 \pm 0.6$ & $0.50 \pm 0.03$ \\
Mature leaves without damage & $50.0 \pm 0.2$ & $55.37 \pm 3.16$ & $82.0 \pm 0.1$ & $0.37 \pm 0.05$ \\
Mature leaves with damage & $50.0 \pm 0.2$ & $55.37 \pm 3.16$ & $65.4 \pm 0.7$ & $0.29 \pm 0.03$ \\
\hline
\end{tabular}


Table 3 Chemical composition and total ion chromatogram (\%) of the essential oils from E. urograndis leaves.

\begin{tabular}{|c|c|c|c|c|c|}
\hline \multirow[b]{2}{*}{ Peak } & \multirow[b]{2}{*}{ Compound } & \multicolumn{4}{|c|}{ TIC (\%) } \\
\hline & & $\begin{array}{c}\text { Young leaves } \\
\text { without } \\
\text { damage }\end{array}$ & $\begin{array}{l}\text { Young leaves } \\
\text { with damage }\end{array}$ & $\begin{array}{c}\text { Mature leaves } \\
\text { without } \\
\text { damage }\end{array}$ & $\begin{array}{c}\text { Mature leaves } \\
\text { with damage }\end{array}$ \\
\hline 01 & Eucalyptol & 28.16 & 10.36 & 20.33 & 7.59 \\
\hline 02 & Linalool oxide <cis-> (furanoid) & 0.25 & 0.20 & 0.19 & 0.13 \\
\hline 03 & Linalool oxide <trans-> (furanoid) & 0.29 & 0.19 & 0.22 & 0.16 \\
\hline 04 & Linalool & 0.60 & 0.57 & 0.57 & 0.49 \\
\hline 05 & NI & 0.40 & 0.06 & 0.1 & 0.05 \\
\hline 06 & Fenchol<endo-> & 0.63 & 0.54 & 0.69 & 0.56 \\
\hline 07 & Campholenal<alpha-> & 0.26 & 0.06 & 0.18 & 0.16 \\
\hline 08 & Borneol & 1.31 & 1.80 & 2.08 & 2.38 \\
\hline 09 & Terpinen-4-ol & 0.99 & 1.18 & 1.43 & 1.38 \\
\hline 10 & $\rho$-Cymen-8-ol & 1.17 & 0.85 & 0.55 & 0.50 \\
\hline 11 & $\alpha$-Terpineol & 10.85 & 11.90 & 11.49 & 13.73 \\
\hline 12 & NI & 1.48 & 0.55 & 0.58 & 0.48 \\
\hline 13 & 2-hydroxy-1,8-cineole & 3.08 & 1.68 & 1.59 & 1.46 \\
\hline 14 & $\begin{array}{l}\text { Neral } \\
\text { Carvone* }\end{array}$ & 0.48 & 0.27 & 0.27 & 0.23 \\
\hline 15 & Geraniol & 0.55 & 0.76 & 0.90 & 1.04 \\
\hline 16 & Geranial & 1.14 & 0.55 & 0.52 & 0.58 \\
\hline 17 & NI & 1.48 & 1.02 & 0.94 & 0.92 \\
\hline 18 & NI & 1.52 & 0.74 & 1.12 & 1.13 \\
\hline 19 & Verbenyl acetate $<$ trans- $>$ & 0.18 & 0.21 & 0.17 & 0.19 \\
\hline 20 & Exo-2-Hydroxycineole acetate & 0.53 & 0.61 & 0.48 & 0.56 \\
\hline 21 & $\alpha$-Terpinyl acetate & 14.24 & 21.06 & 17.62 & 21.96 \\
\hline 22 & NI & 0.35 & 0.33 & 0.34 & 0.37 \\
\hline 23 & Alpha-copaene & 0.27 & 0.40 & 0.30 & 0.38 \\
\hline 24 & Geranyl acetate & 1.67 & 2.26 & 1.65 & 1.89 \\
\hline 25 & NI & 0.82 & 0.33 & 0.32 & 0.48 \\
\hline 26 & Carvone hydrate & 1.27 & 1.53 & 1.49 & 1.55 \\
\hline 27 & NI & 1.02 & 1.15 & 1.20 & 0.91 \\
\hline 28 & Aromadendrene & 0.70 & 1.05 & 0.49 & 0.71 \\
\hline 29 & NI & 1.10 & 1.11 & 1.08 & 1.38 \\
\hline 30 & NI & 1.70 & 2.02 & 2.40 & 2.61 \\
\hline 31 & NI & 0.59 & 0.73 & 0.59 & 0.65 \\
\hline 32 & Geranyl isobutyrate & 2.26 & 3.60 & 3.22 & 4.44 \\
\hline 33 & NI & 1.13 & 1.59 & 1.25 & 1.27 \\
\hline
\end{tabular}




\begin{tabular}{llcccc}
\hline 34 & Flavesone & 0.39 & 0.71 & 0.49 & 0.67 \\
35 & 8-acetoxy-Carvotanacetone & 2.84 & 3.99 & 3.49 & 3.61 \\
& Spathulenol ** & & & & \\
36 & Caryophyllene oxide ** & 7.25 & 12.20 & 10.75 & 12.37 \\
& Globulol ** & & & & \\
37 & Viridiflorol & 0.90 & 1.55 & 2.14 & 2.82 \\
38 & NI & 0.49 & 0.83 & 0.77 & 0.94 \\
39 & Humulene epoxide II & 0.28 & 0.48 & 0.35 & 0.55 \\
40 & Isoleptospermone & 1.58 & 2.64 & 2.39 & 3.21 \\
41 & NI & 2.52 & 4.64 & 1.88 & 2.43 \\
42 & 5-Hydroxy-isobornyl-isobutanoate & 1.16 & 1.62 & 1.29 & 0.97 \\
\hline & Total identified (\%) & $\mathbf{8 5 . 2 8}$ & $\mathbf{8 4 . 8 2}$ & $\mathbf{8 7 . 3 3}$ & $\mathbf{8 6 . 2 7}$ \\
\hline
\end{tabular}

NI: not identified. *Carvone mixed with Neral. ** Caryophyllene oxide and Globulol mixed with Spathulenol. 
Table 4 Variation of the percentage of some compounds in the essential oils of E. urograndis according to the damage.

\begin{tabular}{|c|c|c|c|c|c|c|c|}
\hline \multirow[b]{2}{*}{ Peak } & \multirow[b]{2}{*}{ Compounds } & \multicolumn{6}{|c|}{ TIC (\%) Average } \\
\hline & & $\begin{array}{c}\text { Young } \\
\text { leaves } \\
\text { without } \\
\text { damage }\end{array}$ & $\begin{array}{c}\text { Young } \\
\text { leaves } \\
\text { with } \\
\text { damage }\end{array}$ & $\begin{array}{l}\text { Difference } \\
\quad(\%)\end{array}$ & $\begin{array}{c}\text { Mature } \\
\text { leaves } \\
\text { without } \\
\text { damage }\end{array}$ & $\begin{array}{c}\text { Mature } \\
\text { leaves } \\
\text { with } \\
\text { damage }\end{array}$ & $\begin{array}{c}\text { Difference } \\
(\%)\end{array}$ \\
\hline 01 & Eucalyptol & 28.16 & 10.36 & -63.2 & 20.33 & 7.59 & -62.7 \\
\hline 11 & $\alpha$-Terpineol & 10.85 & 11.90 & 9.6 & 11.49 & 13.73 & 19.5 \\
\hline 21 & $\alpha$-Terpinyl acetate & 14.24 & 21.06 & 47.9 & 17.60 & 22.00 & 25.0 \\
\hline 28 & Aromadendrene & 0.70 & 1.05 & 50.0 & 0.49 & 0.71 & 44.9 \\
\hline 42 & $\begin{array}{l}\text { 5-Hydroxy-isobornyl } \\
\text { isobutanoate }\end{array}$ & 1.16 & 1.62 & 39.7 & 1.29 & 0.97 & -24.8 \\
\hline
\end{tabular}




\section{Figure legends}

Fig. 1 Schematic diagram of the Y-tube olfactometer system.

Fig. 2 Frequency distribution of the $C$. externa larva choice $(\mathrm{n}=$ number of larvae that chose one of the arms) (ns: not significant; $* p<0.05)$

Fig. 3 Structures of the compounds identified in the essential oils from E. urograndis leaves. 
Figure 1

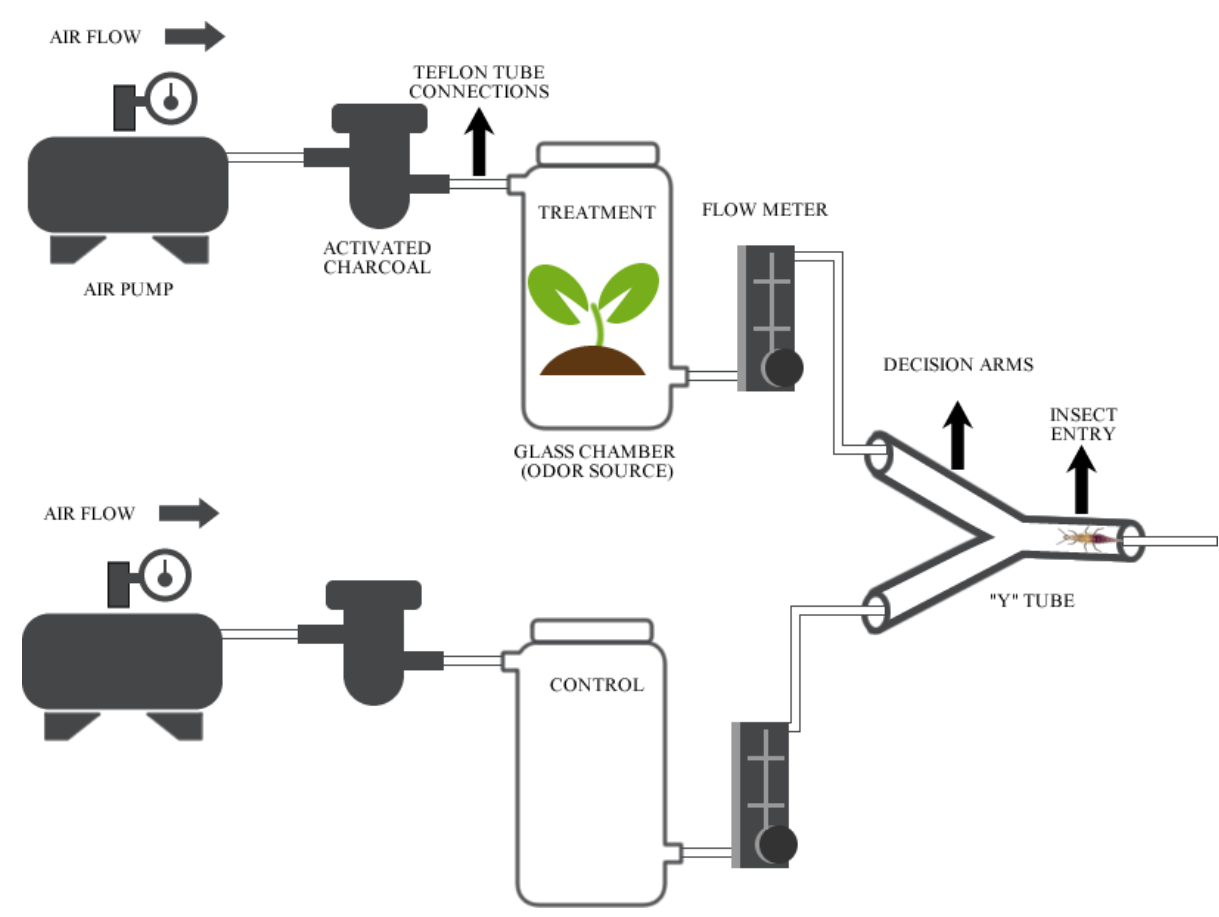




\section{Figure 2}

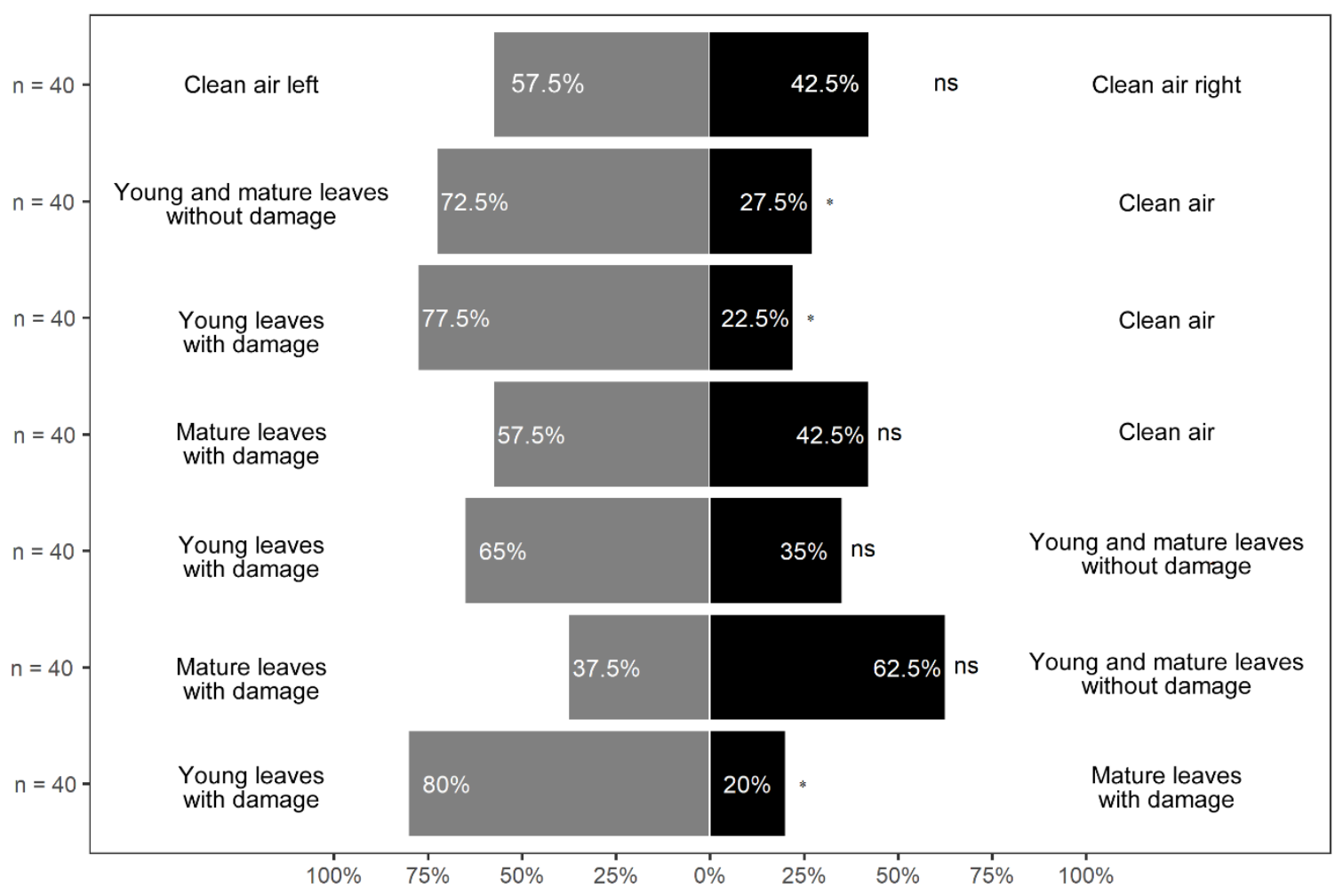


Figure 3

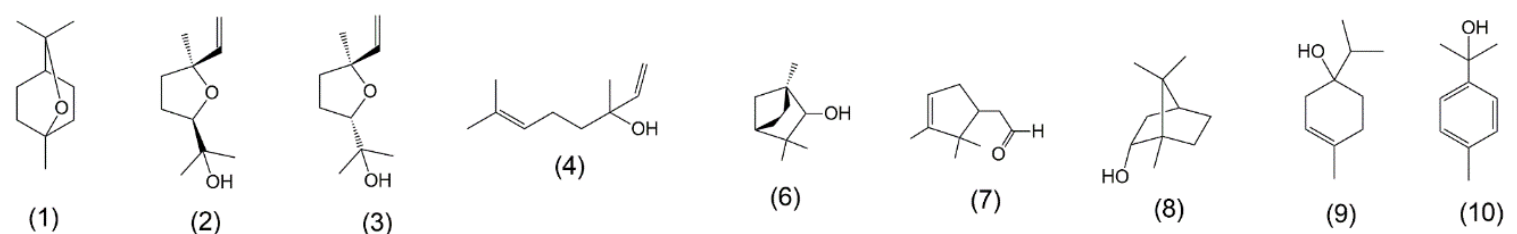

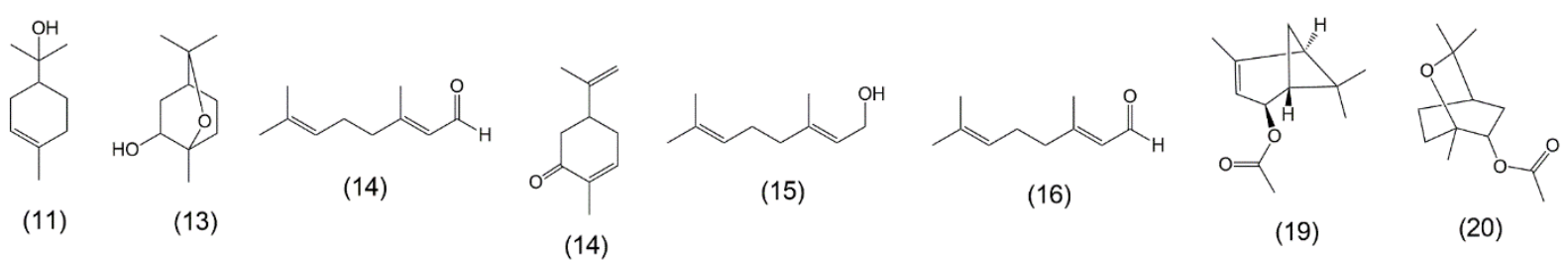<smiles>CC(=O)O/C=C(\C)CCC=C(C)C</smiles><smiles>CCCC(=O)CC12CC(O)C(C1)C2(C)C(C)(C)C</smiles> 
Figures

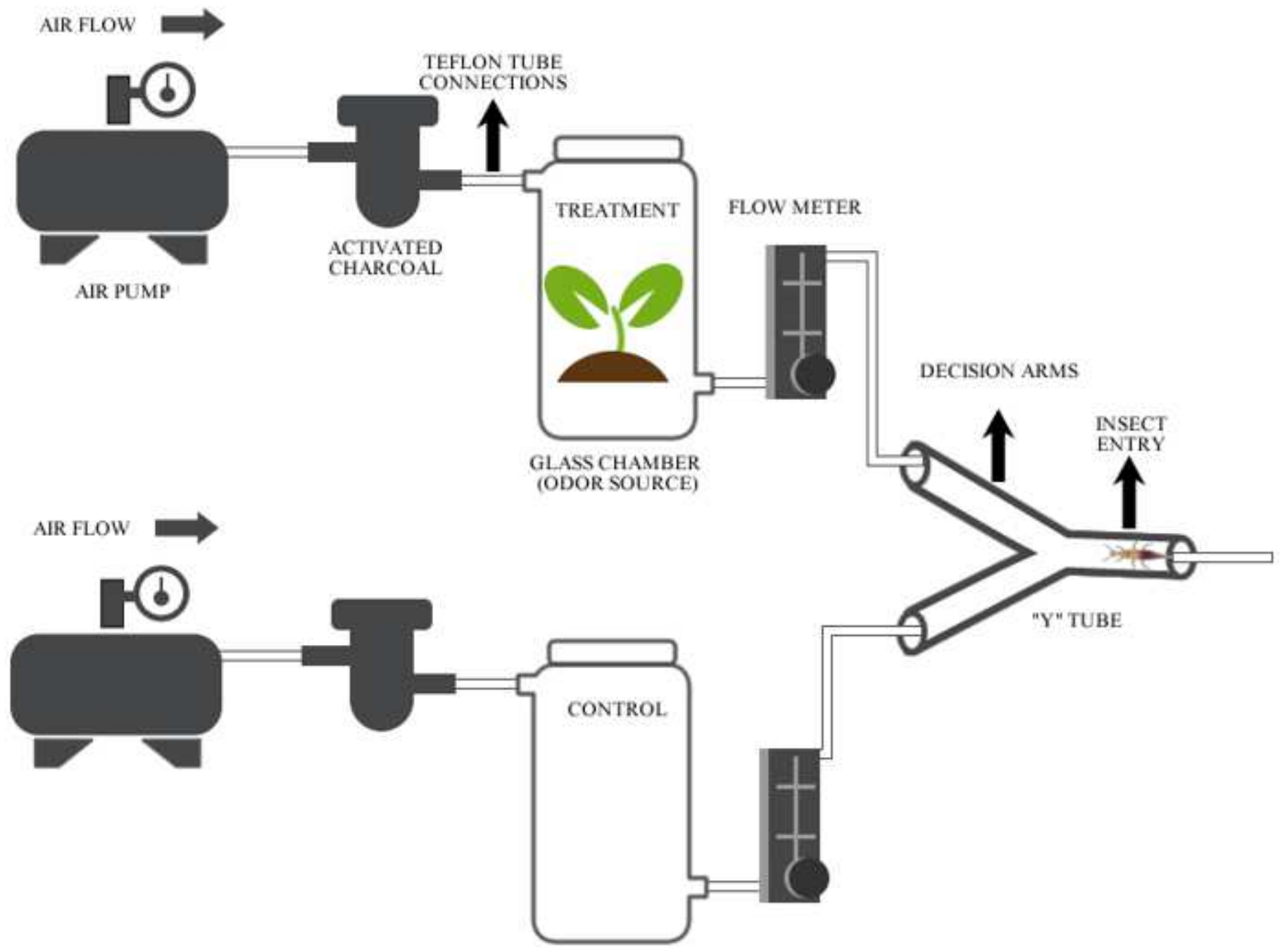

Figure 1

Schematic diagram of the Y-tube olfactometer system. 


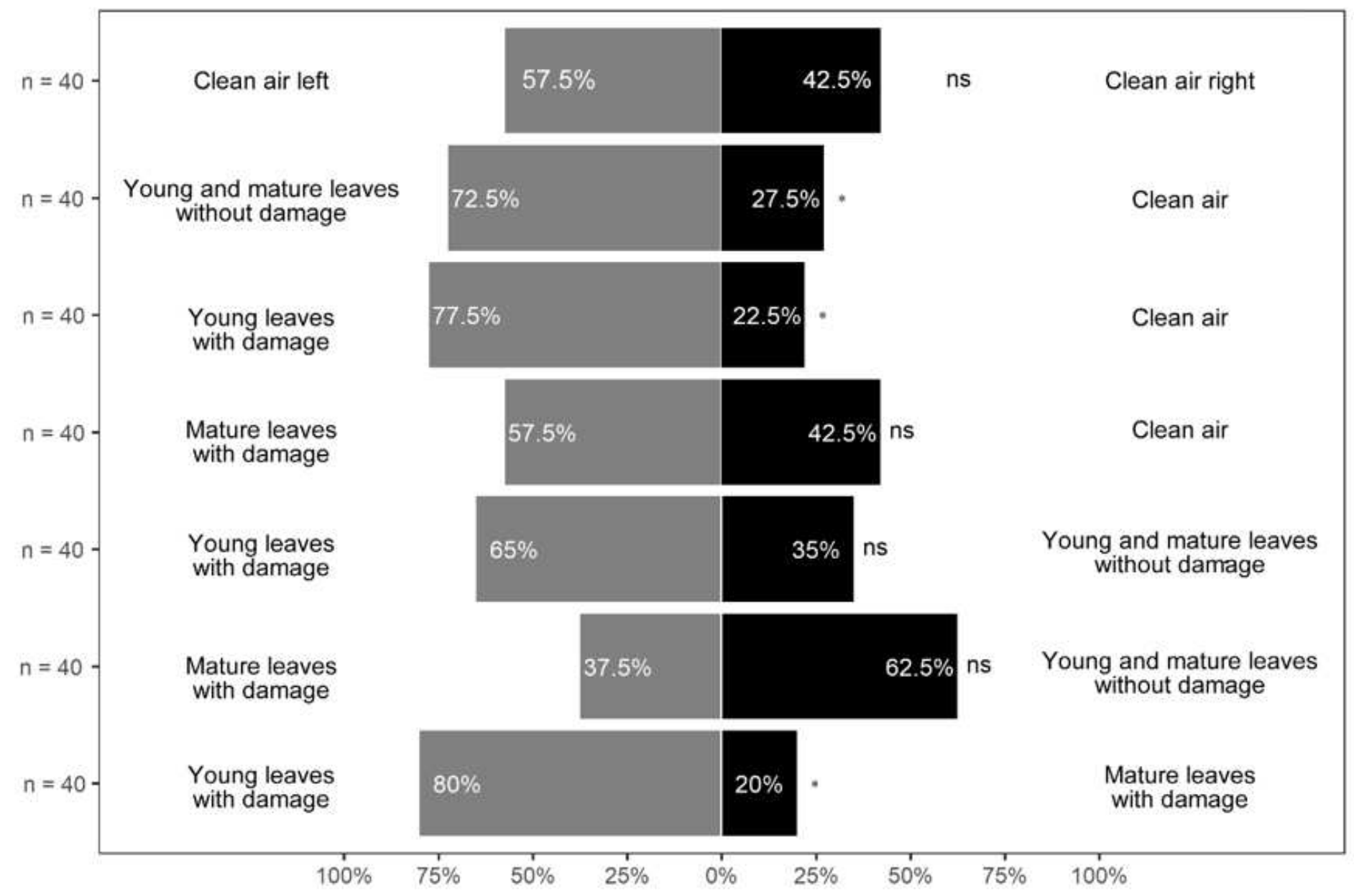

Figure 2

Frequency distribution of the $C$. externa larva choice $(n=$ number of larvae that chose one of the arms) (ns: not significant; ${ }^{*} \mathrm{p}<0.05$ ). 
1

(1)

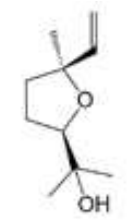

(2)
$\underbrace{}_{O H}$

(3)

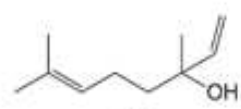

(4)<smiles>CC1(C)C2CCC1(C)C(O)C2</smiles>

(6)<smiles>CC1=CCC2COCC12</smiles>

(7)

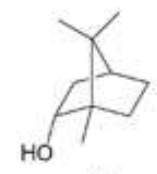

(8)

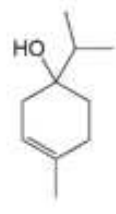

(9)

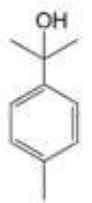

(10)<smiles>CC1CCC(C(C)(C)O)CC1</smiles>

(11)<smiles>CC(C)C12CCC(C)(C)C(CC1O)C2</smiles>

(13)<smiles>C/C=C/C=C(\C)CCC=C(C)C</smiles>

(14)

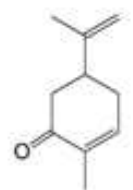

(14)<smiles>CC(C)=CCC/C(C)=C/CO</smiles>

(15)<smiles>CC(C)=CCC=C(C)CCC=C(C)C</smiles>

(16)

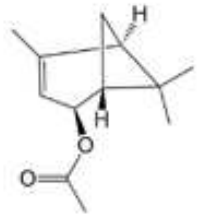

(19)

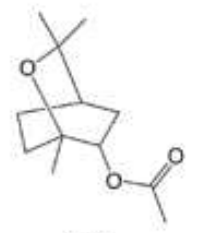

(20)<smiles>CC1=CCC(C(C)C)(C(C)C)CC1</smiles>

(21)

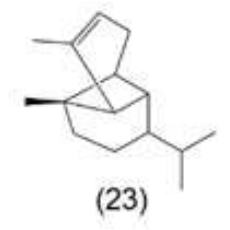

(23)

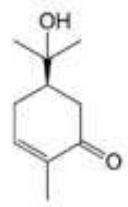

(26)

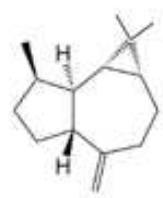

(28)

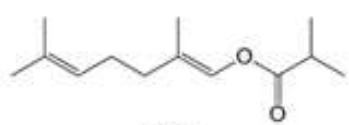

(32)

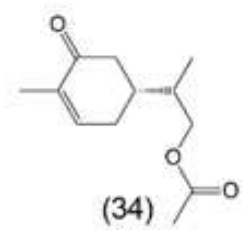<smiles>CC(C)C(=O)C1C(=O)C(C)(C)C(=O)C(C)(C)C1=O</smiles>

(35)

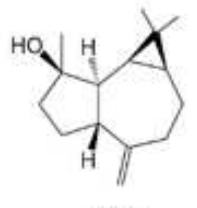

(36)

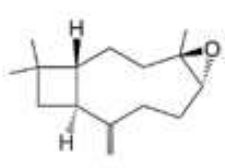

(36)

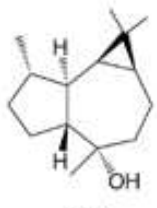

(36)

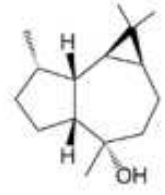

(37)

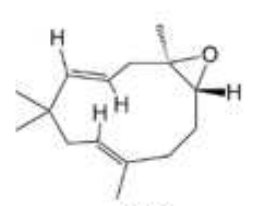

(39)

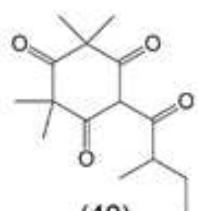

(40)

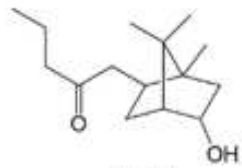

(42)

Figure 3

Structures of the compounds identified in the essential oils from E. urograndis leaves.

\section{Supplementary Files}

This is a list of supplementary files associated with this preprint. Click to download.

- supplementarymaterial2a.opcaofigmodif12052021.docx 